\title{
Managing Internationalisation of Higher Education: Strategic Planning and Assessment
}

\author{
Nadezhda V. Krasilnikova* \\ Mari State University \\ 1 Lenin Sq., Yoshkar-Ola, 424000, Russia
}

Received 20.08.2014, received in revised form 28.12.2014, accepted 15.05.2015

Internationalisation is currently among the key objectives of higher education institutions (HEIs) worldwide, particularly in the Bologna signatory states. Measures which are being introduced at the international and national levels with the purpose to promote internationalisation differ in their scope and application depending on the context. The paper covers the issues related to the development of both internationalisation at home and internationalisation abroad. A few examples of good practices in fostering internationalisation are also provided. Since internationalisation is considered to be beneficial for a large number of stakeholders, many assessment tools are currently being developed and implemented to measure it. The paper provides a brief overview of the existing assessment tools as well as the analysis of two European methods used to evaluate internationalisation.

Keywords: internationalisation at home; internationalisation abroad; internationalisation strategy; measuring internationalisation.

DOI: 10.17516/1997-1370-2015-8-8-1635-1641.

Research area: economics, pedagogy.

\section{Introduction}

Internationalisation is currently considered to be beneficial for all stakeholders involved in higher education. Students aim to get relevant skills for the global market. Employers recognise the value of international experience and require graduates to have intercultural competency. National governments consider internationalisation to be an asset to the higher education system since it can influence national competitiveness on the global arena of higher education. Hence, higher education institutions
(HEIs) are encouraged to develop and implement internationalisation strategies to meet the needs of various stakeholders including HEIs themselves.

Since internationalisation plays a mainstream role in higher education all stakeholders call for accountability and quality assurance. Students, faculty, researchers, management of HEIs, employers as well as national and international authorities want to make sure that internationalisation strategies are implemented effectively and efficiently,

(C) Siberian Federal University. All rights reserved

* Corresponding author E-mail address: krasilnikovanv@gmail.com 
as well as beneficial for all the parties. Thus, many procedures aimed at measuring internationalisation are currently being developed and applied.

\section{Basic approaches to internationalisation}

Internationalisation is not a new concept, but it has evolved over the past seventy years. It has undergone a shift in focus from cooperation between HEIs to competition on preparation of students as well as employment of highly qualified and competent staff and acquisition of additional funding. Internationalisation is seen to be an asset to HEIs. The main rationales and incentives of internationalisation are political, economic, academic, cultural and social (Knight \& De Wit, 1995). These rationales are interconnected and should be taken into account while regarding governments' as well as HEIs' steps toward the incorporation of internationalisation into their strategies and activities. In order to develop an efficient internationalisation strategy people involved in this process should have a clear understanding of this multifaceted process.

The concept of internationalisation in higher education has been widely studied by academic and research communities, and the interpretations of internationalisation are rather diverse. Internationalisation is most commonly defined as "a process of integrating an international and cultural dimension into the teaching, research and service functions of the institution" (Knight, 2008: 20). There are a large number of other researchers (J. Hudzik, E. Jones, U. Teichler, B. Wächter, M. van der Wende, H. de Wit, and many others) addressing internationalisation issues in their papers. J. Hudzik (2012: 3) provides a definition of comprehensive internationalisation, which is "a commitment, confirmed through action, to infuse international and comparative perspectives throughout the teaching, research, and service missions of higher education". Currently researchers distinguish between "internationalisation at home" and "internationalisation abroad".

"Internationalisation at home" or as it is called "internationalisation of the curriculum" is "the incorporation of an international and intercultural dimension into the content of the curriculum as well as the teaching and learning arrangements and support services of a program of study" (Leask, 2009: 209). An internationalised curriculum is regarded to be "a curriculum which gives international and intercultural knowledge and abilities, aimed at preparing students for performing (professionally, socially, emotionally) in an international and multicultural context" (Nilsson 2000: 22).

The necessity to promote internationalisation at home emerges as many HEIs realise that only a small proportion of their students take part in academic exchange programmes. In the Leuven/ Louvain-la-Neuve Communiqué the European governments formulated the mobility target that "in 2020, at least $20 \%$ of those graduating in the EHEA should have had a study or training period abroad" (Leuven/Louvain-la-Neuve Communiqué, 2009). But in spite of a myriad of initiatives aimed at the development of academic mobility, the proportion of mobile students does not currently reach this level.

Since future graduates will have to live and work in multicultural environments domestically and internationally, and find solutions to global problems, HEIs strive to provide their students with the opportunity to acquire intercultural (global) competency without necessarily leaving their home institutions.

D. Van Roekel defines global competency as "the acquisition of in-depth knowledge and understanding of international issues, 
an appreciation of and ability to learn and work with people from diverse linguistic and cultural backgrounds, proficiency in a foreign language, and skills to function productively in an interdependent world community" (National Education Association, 2010: 1).

Therefore, HEIs committed to implementing internationalisation at home strategies elaborate on their curricula in a way to prepare students for life and work in a globalised world.

There are a few universities worldwide fostering internationalisation at home, University of Alberta International and Monash University (Canada), University of Bremen (Germany), Malmö University (Sweden), University of Groningen (Netherlands), University of Minnesota (USA) are among them. The internationalisation strategy of University of Minnesota incorporates the following activities: 1) developing the academic staff; 2) identifying learning outcomes; 3) expanding teaching strategies; 4) developing materials, activities, and assessments (University of Minnesota, 2010). Thus, the University planned first to elaborate on intercultural communication strategies and identify global competencies as well as appropriate learning outcomes and then review the content of the curriculum as well as the course materials and incorporate relevant activities, assignments and assessments.

Russian HEIs do not have substantial experience in internationalising their curricula, but a few steps are being taken. A great number of universities deliver study programmes in English, organise international summer schools and involve their students in international research projects.

"Internationalisation abroad" encompasses such activities as: academic mobility of students, staff and researchers; mobility of study programmes (joint / double degree programmes etc) and providers of higher education, international partnerships and projects (Knight, 2008: 23-24).

Internationalisation abroad is currently undergoing drastic changes as new forms of HEIs and study programmes emerge. They are, for instance, twinning and franchising arrangements, international branch campuses, and education hubs. These activities constitute institutional / programme mobility in contrast to academic mobility of students, staff and researchers.

Since these are quite recent trends, there are no agreed upon definitions of these processes. One of the key difficulties for researchers aspiring to come up with unified definitions is that there is no "one size fits all" approach when dealing with internationalisation. Nevertheless there are a few terms that provide general understanding of these manifestations of transnational education:

- Twinning programmes are delivered when "a provider in source Country A collaborates with a provider in Country B to develop an articulation system that allows students to take course credits in Country B and/or in source Country A" (Knight, 2006: 24). A qualification is awarded by the provider in source Country A.

- Franchising is "a process by which an awarding institution agrees to authorise another organisation to deliver (and sometimes assess) part or all of one (or more) of its own approved programme" (Code of practice, 2010).

- An international branch campus is "a satellite operation of a recognized higher education institution or provider which offers academic programs and credentials in a different country than the home institution" (Knight, 2014: 18).

- An education hub is "a planned effort by a country (or zone, city) to build a critical mass of local and international actors 
strategically engaged in crossborder education, training, knowledge production and innovation initiatives" (Knight, 2014: 19-20).

Though internationalisation abroad is more developed in the counties belonging to the European Union as well as the USA and a few Asian countries (China, Korea, Singapore, Japan and Malaysia), Russian universities actively promote a variety of activities aimed at enhancing their internationalisation. Even such small regional universities as Mari State University and Volga State University of Technology encourage academic mobility of students and staff members who take part in Erasmus Mundus, DAAD (German Academic Exchange Service) and Fulbright programmes; departments of both institutions are involved in Tempus projects and collaborate with foreign universities.

Hence, there are currently many opportunities for HEIs seeking to enhance their internationalisation. No doubt, various HEIs have diverse aspirations with regard to internationalisation, so their strategies have different core activities to be promoted.

B. Jenkins-Deas (2009:112) compares internationalisation to the process of building a house, which involves drawing architectural plans. Like the process of internationalisation a house has got a foundation, a certain order and type of construction, depending on the region and the owner's taste, and it is never completely finished, as it may be repaired and redecorated.

Since internationalisation offers numerous benefits for the key stakeholders in higher education, they want to be sure that the activities are effective and efficient. This call for accountability encourages organisations involved in higher education quality assurance procedures to develop and implement instruments to assess internationalisation.

\section{Assessment of internationalisation in higher education}

Most procedures applied to measure internationalisation of higher education involve academic rankings, self-evaluation, accreditation, audit and benchmarking. The choice of a relevant assessment tool depends on the purpose of evaluation.

There are three basic objectives of measuring internationalisation: "1. Knowing where your organisation stands (mapping) in terms of internationalisation 2. Examining the value of the internationalisation efforts (evaluating) and 3. Setting an organisational identity (profiling), showing both internal and external stakeholders the strengths and ambitions of your organisation from an internationalisation perspective" (Beerkens, 2010: 9).

John Hudzik and Michael Stohl also emphasise that internationalisation activities should be aligned with the overall missions and goals of HEIs. Consequently, assessments should simultaneously look at the particular outcomes of internationalisation and their contribution to the implementation of HEIs' overall objectives (Hudzik, 2009).

In general, most indicators applied to measure internationalisation are aimed at assessing: "inputs: resources (money, people, policies, etc) available to support internationalisation efforts; outputs: the amount and types of work or activity undertaken in support of internationalisation efforts; and outcomes: impacts or end results" (Hudzik, 2009: 14). The set and number of indicators are either specified in the existing assessment tools or chosen by HEIs themselves.

For instance, in a self-evaluation procedure "theinternalsituationismeasuredagainstobjective indicators, which have been determined by the organisation (e.g. on the basis of the objectives formulated in the institution's policy paper or strategic plan) or against performance targets 
imposed by external parties (e.g. in government directives or accreditation procedures)" (Van Gaalen, 2009: 78).

Unlike self-evaluation exercises, accreditation and audit procedures include an external review panel site visit to a HEI. Since peer reviewers can take into account the factors which are hard to quantify, their assessments and recommendations are considered to be valuable.

There are currently numerous methodologies of the abovementioned procedures. Many of them are based on the previously developed indicators. Thus, there are a number of tools stemming from the initiative launched by four German HEIs and the Centre for Higher Education Development (CHE) in 2006. In the CHE tool, internationalisation is measured against $186 \mathrm{key}$ numbers and indicators, which are all grouped into three categories: overall aspects, academic research, teaching and studies. These broad categories are subdivided into smaller units to measure internationalisation in numbers with regard to professors, young researchers, administrative staff, resources, international networking and international research projects, lectures, students, service and administration, study programmes/curricula, graduates and international reputation. There are also ten yes/no questions to assess the management of internationalisation (Brandenburg, 2009). This assessment tool can be used by HEIs to monitor the implementation of their internationalisation strategy or serve as a preliminary procedure when they aspire to undergo an external peer review (accreditation, audit, and certification).

Until recently internationalisation was not separately assessed within accreditation procedures. In 2012, the European Consortium for AccreditationinHigherEducation(ECA) launched a project aimed at developing a methodology to assess the quality of internationalisation (Aerden, 2014). Upon successful completion of a peer review procedure, HEIs will be awarded a Certificate for Quality of Internationalisation. The assessment is carried out at programme and institutional levels. The programme evaluation is focused on the internationalisation goals (intended internationalisation) as well as international and intercultural learning outcomes, and the factors (teaching and learning, staff and students) which have a strong impact on students' performance with regard to the acquisition of these learning outcomes.

The assessment of institutional performance related to internationalisation is conducted against the following groups of standards: intended internationalisation, action plans, implementation, enhancement and governance. Thus, internationalisation is regarded here as part of the institutional quality assurance system. The distinguishing feature of this methodology is that internationalisation is addressed here as a contextual process.

A wide variety of existing assessment tools provides HEIs with the opportunity to choose the most reasonable and appropriate one or develop their own.

\section{Concluding remarks on the implementation of the internationalisation concept}

Internationalisation in higher education is considered to be a valuable force in enhancing the quality of education and gaining further benefits. This view is backed by strategies, policies and initiatives implemented at international and domestic levels. Hence, HEIs worldwide take much effort to pursue internationalisation. In order to maximise the potential of internationalisation, they develop and implement internationalisation strategies to carry out periodic assessment of their performance. Although there are currently many theoretical studies and practical applications of 
the concept of internationalisation, there are no uniform approaches to this multidimensional process. Thus, internationalisation strategies as well as implementation monitoring should be tailored to the context in which these HEIs operate.

\section{References}

1. Aerden, A. (2014). A Guide to Assessing the Quality of Internationalisation. European Consortium for Accreditation, $32 \mathrm{p}$.

2. Beerkens, E., Brandenburg, U., Evers, N., Van Gaalen, A., Leichsenring, H., Zimmermann, V. (2010). Indicator Projects on Internationalisation - Approaches, Methods and Findings. A report in the context of the European project "Indicators for Mapping \& Profiling Internationalisation" (IMPI), CHE Consult GmbH, Gütersloh, 141 p.

3. Brandenburg, U., Federkeil, G. (2009). How to measure internationality and internationalisation of higher education institutions! Indicators and key figures. In CHE Working paper 92.

4. Code of practice for the assurance of academic quality and standards in higher education Collaborative provision and flexible and distributed learning (including e-learning) - Amplified version October 2010. 86 p.

5. Hudzik, J. \& McCarthy, J. (2012). Leading Comprehensive Internationalization: Strategy and Tactics for Action. NAFSA: Association of International Educators, $24 \mathrm{p}$.

6. Hudzik, J. \& Stohl, M. (2009). Modelling assessment of the outcomes and impacts of internationalisation. In H. de Wit (Ed.), Measuring success in the internationalisation of higher education. EAIE Occasional Paper, 22, pp. 9-21.

7. Jenkins-Deas, B. (2009). The impact of quality review on the internationalisation of Malaspina University-College, Canada: a case study. In H. de Wit (Ed.), Measuring success in the internationalisation of higher education. EAIE Occasional Paper, 22, pp. 111-124.

8. Knight, J. (2006). Higher Education Crossing Borders: A Guide to the Implications of the General Agreement on Trade in Services (GATS) for Cross-border Education. 76 p.

9. Knight, J. (2008). Higher Education in Turmoil. The Changing World of Internationalisation, Rotterdam: Sense Publishers, 241 p.

10. Knight, J. (2014) International Education Hubs: Student, Talent, Knowledge-Innovation Models. 251p. doi 10.1007/978-94-007-7025-6_1.

11. Knight, J. \& De Wit, H. (1995) Strategies for internationalisation of higher education: historical and conceptual perspectives, in H. de Wit (Ed.) Strategies for Internationalisation of Higher Education: a comparative study of Australia, Canada, Europe and the United States. Amsterdam: European Association for International Education. pp 5-33.

12. Leask, B (2009). Using formal and informal curricula to improve interactions between home and international students. Journal of Studies in International Education, vol. 13, no 2, pp. 205-221.

13. National Education Association (2010). Global competence is a $21^{\text {st }}$ century imperative. available at http://www.nea.org/assets/docs/HE/PB28A_Global_Competence11.pdf (accessed 17 May 2014).

14. Nilsson, B. (2000). Internationalising the curriculum. Internationalisation at Home, A Position Paper, Amsterdam, EAIE, pp. 21-27. 
15. The Bologna Process 2020 - The European Higher Education Area in the new decade. Communiqué of the Conference of European Ministers Responsible for Higher Education, Leuven and Louvain-la-Neuve, 28-29 April 2009, available at http://www.ehea.info/Uploads/Declarations/ Leuven_Louvain-la-Neuve_Communiqu\%C3\%A9_April_2009.pdf (accessed 7 October 2013).

16. University of Minnesota: Internationalizing Teaching and Learning. Pilot Project for Fall Semester 2010. available at http://global.umn.edu/icc/teaching-learning.html (accessed 5 April 2014).

17. Van Gaalen, A. (2009). Developing a tool for mapping internationalisation: a case study. In H. de Wit (Ed.), Measuring success in the internationalisation of higher education. EAIE Occasional Paper, 22, pp. 77-91.

\section{Управление интернационализацией высшего образования: \\ стратегическое планирование и оценка}

Н.В. Красильникова Марийский государственный университет Россия, 424000, Йошкар-Ола, пл. Ленина, 1

В настоящее время интернационализащия является ключевой задачей высших учебных заведений (вузов) по всему миру, в частности в странах - участницах Болонского соглашения. Меры, предпринимаемые на международном и национальном уровнях с целью способствовать интернационализации, различаются по содержанию и формам реализаџии в зависимости от контекста. В данной статье рассматриваются проблемы, связанные с развитием внутренней и внешней интернационализации. Также представлены примеры хороших практик по развитию интернационализации. В связи с тем что интернационализация имеет практическую значимость для большого количества заинтересованных лии, в настоящее время разрабатываются и применяются инструменты для ее оценки. В статье представлен краткий обзор существующих методов оценки и анализ двух европейских методов, применяемых для оценки интернационализации.

Ключевые слова: внутренняя интернационализация, внешняя интернационализация, стратегия интернационализации, оценка интернационализации.

Научная спеииальность: 08.00.00 - экономические науки, 13.00.00-педагогические науки. 